\title{
Vil ikke se, vil ikke høre, vil ikke snakke: om menns vold mot kvinner og selvmordsatferd
}

Tove Smaadahl intervjues av Dag W illy Tallaksen.

\section{I juni 2003 holdt daglig leder av Krisesentersekretariatet Tove Smaadahl foredrag på SSFFs fore-} byggingsforum i Oslo. Foredraget inneholdt en rekke tankevekkende utsagn om kvinner som hadde vaert utsatt for vold i hjemmet. Smaadahl viste til at landets krisesentre har mye erfaring som tyder på at det er en tett sammenheng mellom vold og selumordsatferd blant mishandlede kvinner.

\section{Det ville vi gjerne vite mer om.}

$\AA$ avtale et intervju var ikke vanskelig å få til, men hvor i all verden befinner Krisesentersekretariatet seg? På den oppgitte adresse finnes intet som tyder på hvilken aktivitet som foregår bak veggene. $\mathrm{H}$ er var ingen logo eller navn, kun en ringeklokke med teksten Resepsjon. I et kontorfelleskap med flere kvinne- og utviklingsorganisasjoner fant tidsskriftets medarbeider imidlertid fram, og ble tatt vel i mot av en engasjert Smaadahl, som er den eneste ansatte i organisasjonen.

I rapporten Livsmuligheter? - om selvmord og selvmordsforsøk blant mishandlede kvinner som nylig ble publisert av K risesentersek retariatet, finnes føl gen de historie som kan tjene som et utgangspunkt for vår samtale.

"Politiet kom til krisesenteret med Kari og hennes tre barn om natta. H un var i en sjokklignendetilstand, og satt mer eller mindre apatisk å så på at de ansatte tok vare på barna som gråt og var redde. $M$ annen hadde rasert hele leiligheten den kvelden, og han hadde rispet $\mathrm{K}$ ari med kniv i ansiktet. $\mathrm{N}$ aboene hadde varslet politiet.

D agen etterpå låste $K$ ari seg inn på badet på krisesenteret. $H$ un hadde tatt med seg brødkniven. H un gråt og ropte fortvilet at nå orket hun ikke mer. $\mathrm{H}$ un hadde levd $\mathrm{i}$ et voldshelvete i 8 år, og der og da så hun ingen annen løsning enn døden. M ed ekstranøkkel fikk de ansatte avverget selvmordsforsøket, og legehjelp ble tilkalt."

Slike hendelser har vi opplevd altfor mange av rundt om på lan dets krisesentre i løpet av de siste årene, sier Smaadahl. - Vi skulle ønske vi visste mer om omfanget og forholdene rundt selvmord og selvmordsforsøk hos de som oppsøker oss. Det kan virke som om det finnes en form for motstand mot denne type kunnskap. $\mathrm{Vi}$ opplever også at myndighetene er for passive i forhold til gruppen, fortsetter hun.

Raskt legger hun til at K vinnevoldsutval get overleverte justisminister $0 \mathrm{dd}$ Einar Dørum N OU 2003: 31 "Retten til et liv uten vold" i desember 2003.
- H er skisseres en rekke nødvendige tiltak. Det viktigste er at det her blir dokumentert at myndighetene ser at vi står overfor et betydelig problemområde. $\mathrm{Vi}$ savner fortsatt kompetanse og organisering av hjel petilbudet. Samtidig er det viktig at det offentlige tar ansvar for finansieringen av krisesentrene og andre lavterskeltilbud som skal bistå de voldsutsatte, sier Smaadahl. H un viser til et eksempel som forteller hvor stort hjelpebehovet kan være i enkeltsaker. En kvinne som bodde på krisesenteret hadde behov for hjelp fra hele 55 instanser i reetableringsfasen. D ette gir en indikasjon på hvor viktig det er med et organisert hjelpetilbud som støtter kvinnene gjennom prosessen til et selvstendig liv uten vold.

O g hun fortsetter: - Vold mot kvinner og deretter følgende selvmordsatferd er i forsvinnende liten grad gitt rom i fagog undervisningsplanene til yrkesgrupper innen helse- og sosialsektoren. Verken leger, psykologer eller andre hel searbeidere har vist påfallende stor interesse for à ta opp de utfordringer som er forbundet med vold og mishandling av kvinner. $\mathrm{H}$ un påpeker at utviklingen innen dette området går util givelig langsomt. Det nærmeste vi kommer at det offentlige hittil har tatt problemet på alvor, er å finne i politietaten som har utarbeidet en håndbok om familievold. Det står fortsatt svært mye ugjort, - f.eks. er rutiner knyttet til mottak av voldtatte kvinner fortsatt ikke kvalitetssikret, påpeker Smaadahl.

- Vi er sosial isert til å se på familien som det beste sted for kjærlighet, omsorg og utfoldelse. Dessverre blir familien for noen et personlig helvete hvor tanken på døden kan komme som en befrielse. Slike forhold snakkes det nesten ikke om. Kan det være at vi er språkløse, at vi mangler et vokabular for å uttrykke de opplevelser som ligger implisitt i kvinners voldshelvete? spør Smaadahl. - Er dette for privat til å snakkes om? M ekanismene i det som skjer, fører ofte til at de som utsettes for fornedrende vold ser på seg selv som skyldige, noe som ytterligere forsterker vanskelighetene ved å snakke om det. K vinnene det gjelder rammes av dobbelt tabuisering; de er både mishandlede og de tenker å ta sine liv. Det blir for vanskelig for de fleste av oss å nærme seg noe som er så komplisert og utfordrende på en gang. $\mathrm{H}$ vilket medfører at tausheten får råde, konstaterer Smaadahl.

M en nœe må vi da vite om størrelsen på dette problemet?

- Jo da, vi vet med rimelig sikkerhet at selvmordstanker er utbredt blant kvinner som bor og har bodd på våre krisesentre. I Sverige ble det nylig publisert en undersøkelse med det talende navn Slagen dam. $M$ an fant der at kvinner som har vært utsatt for vold "noen gang", har mye hyppigere selvmordstanker sammenlignet med kvinner som aldri har vært utsatt for vold. Blant de kvinner som bekreftet at de hadde vært utsatt for vold de siste 12 måneder, fant man at hyppigheten av selvmordsforsøk var nærmere fire ganger så stor som blant kvinner som ikke hadde vært utsatt for vold. Dersom kvinnene hadde vært utsatt for seksualisert vold, var tallene enda mer alarmerende.

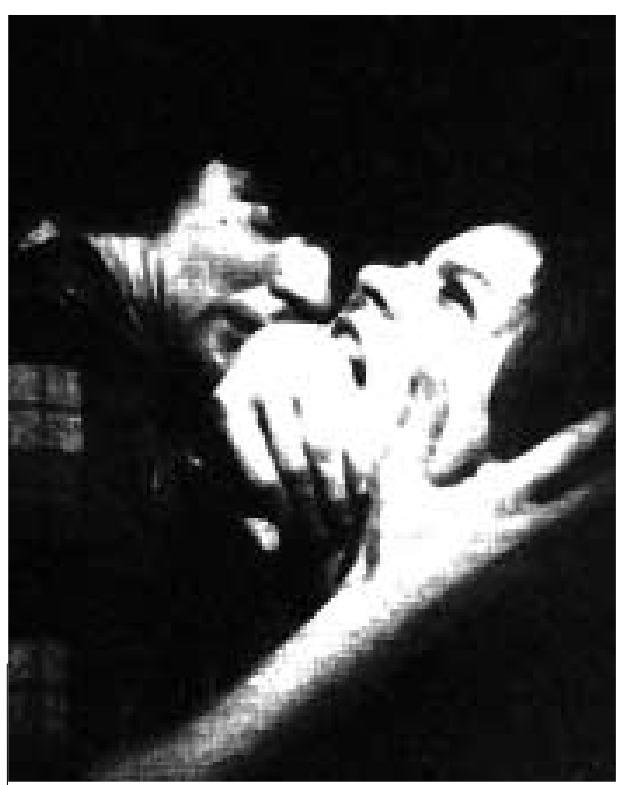


I denne gruppen var selvmordsforsøk ca. 5 ganger så hyppig som blant de kvinner som ikke hadde vært utsatt for vold eller overgrep. H ele $14 \%$ av de som hadde vært utsatt for seksuell vold de siste 12 måneder, oppga at de hadde forsøkt å ta sitt liv.

- A leve under trusler om mishandling og død utløser for noen et ønske om å fă dø, fortsetter Smaadahl. I de mest ekstreme tilfeller drives kvinnen til selvmord, eller ut i et rusmisbruk som omgivelsene altfor raskt mistolker som et bevis på hennes sosiale utilstrekkelighet. I og med at samfunnet har idealisert familien, kan det for enkelte kvinner være vanskelig å snakke om volden som begås i hjemmet. Mødre er ofte villige til å strekke seg langt for å holde familien samlet, samtidig er de redd for konsekvensene ved et brudd. $M$ ange menn fortsetter med trusler og vold etter bruddet, og mange kvinner frykter et liv i fattigdom, spesielt kvinner uten eller med begrensede inntekter. Det er dette landets krisesentre har mye erfaring med, sier Smaadahl, og viser til et eksempel som er gjen gitt i rapporten Livsmuligheter?

"Etter 14 dager på krisesenteret bestemte hun seg for å gi mannen en ny sjanse. $\mathrm{H}$ an hadde lovet henne å søke hijelp for sine voldsog aggresjonsproblemer. Fem måneder senere kunne vi lese dødsannonsen hennes i avisen. $\mathrm{H}$ un hadde tatt sitt eget liv."

- Vi, det vil si omverdenen inkludert offentligheten, må lære hva vi skal se etter og vi må vise mot til å gjøre noe med det vi ser, sier Smaadahl. Slikt mot har ofte vært mangelvare, og her legger hun til at i den grad det finnes så er det hos radikale kvinner. $\mathrm{N}$ år de mishandlede kvinnene kommer til krisesentrene og $\mathrm{i}$ ro og mak får hjelp til å sette ord på smerten, er de aller fleste villig til å ta i mot hjelp. Det faller en liten kommentar fra Smaadahl om at hjelpeapparatet er nokså utilstrekkelig, men noe finnes dog, f. eks. gjør både enkel tpersoner og de som jobber med prosjektbaserte tiltak en god jobb, påpeker hun. Videre stiller hun spørsmål om usikkerheten rundt taushetsplikten er noe helse- og sosial personell skjuler seg bak for å slippeå gå inn i dette kompliserte landskapet.

- De siste årene har vi sett en utvikling i retning av at flere og flere kvinner med innvandrerbakgrunn oppsøker krisesent- rene, sier Smaadahl. For kvinner som kommer fra mer patriarkalske samfunn, kan det å bryte ut av et ekteskap være forbundet med skam. M ange av kvinnene blir utstøtt av sitt miljø, og de er redde for å bli sendt tilbake til hjemlandet som skilt og stigmatisert kvinne. Tabuiseringen er sterk. Det er grunn til å se nøye på selvmordtallene blant kvinner med minoritetsbakgrunn. Vi blir fortalt at den er lav, men vet vi nok om dette? spør Smaadahl.

\section{$H$ va tenker du om hvorfor mange menn er så tause om problemstillingene knyttet} til kvinnemishandling?

- Det er viktig at majoriteten av menn som ikke utøver vold, står fram og tar avstand fra vold, svarer hun. M enn som slår, må ta ansvaret for den volden de utøver. O fte er det slik at han skylder på henne, og kvinnene har tradisjon for å ta på seg skylden. K vinnene strekker seg som nevnt langt for kjærligheten, og for barna. M itt ønske er at vi kommer dit at menn som slår, innrømmer det de har gjort, og i neste omgang innser at de trenger behandling og hjelp. A komme dit at disse mennene vedstår seg at de har slått, vil være et stort framskritt, avslutter Smaadahl.

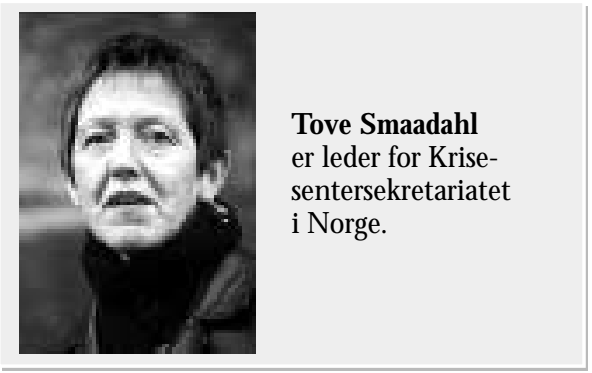

D ag Willy Tallaksen er redaksjonsmedlem i Suicidologi og høgskol elektor ved $\mathrm{H} ø g s k o l e n$ i A kershus, Avd. for sykepl eierutdanningen.

\section{Referanser}

Lundgren, Eva (m.fl.): Slagen dam: mäns våld mot kvinnor $i$ jämställda Sverige. - en omfångsundersökning. U meå : Brottsoffermyndigheten ; Stockholm: Fritzes offentliga publikationer, 2001. - $140 \mathrm{~s}$.

Retten til et liv uten vold : menns vold mot kvinner i nære relasjoner. 0 slo: Statens forvaltningstjeneste, Informasjonsforvaltning, 2003. - $234 \mathrm{~s}$ ( $N$ orges offentlige utredninger (N OU) ; 2003: 31)

Smaadahl, Tove: Livsmuligheter? : om selvmordsforsøk og selvmord blant mishandlede kvinner/ Tove Smaadahl og U nni Kiil. O slo: Krisesentersekretariatet, 2003.

\section{Luka}

My name is Luka

I live on the second floor

I live upstairs from you

Yes I think you've seen me before

If you hear something late at night Some kind of trouble, some kind of fight

Just don't ask me what it was

Just don't ask me what it was

Just don't ask me what it was

I think it's because I'm clumsy

I try not to talk too loud

Maybe it's because I'm crazy

I try not to act too proud

They only hit until you cry

And after that you don't ask why

You just don't argue anymore

You just don't argue anymore

You just don't argue anymore

Yes I think I'm okay

I walked into the door again

Well, if you ask that's what I'll say

And it's not your business anyway

I guess I'd like to be alone

With nothing broken, nothing thrown

Just don't ask me how I am

Just don't ask me how I am

Just don't ask me how I am

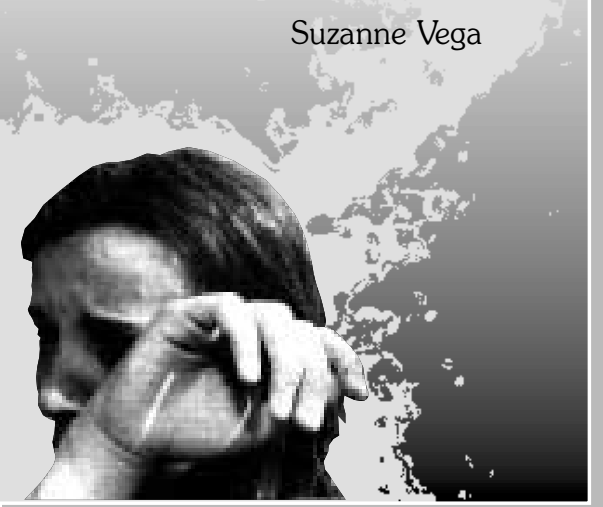

